\title{
Ikääntyvien terveystietokäyttäytyminen ja hyödylliseksi koetut digitaaliset terveyspalvelut
}

\author{
Isto Huvila \\ Uppsala universitet, Ábo Akademi \\ isto.huvila@abo.fi \\ https://orcid.org/0000-0001-9196-2106
}

\author{
Heidi Enwald \\ Oulun yliopisto, Åbo Akademi \\ heidi.enwald@oulu.fi \\ https://orcid.org/0000-0003-1953-2157 \\ Kristina Eriksson-Backa \\ Åbo Akademi \\ kristina.eriksson-backa@abo.fi \\ https://orcid.org/0000-0001-9758-0467
}

\author{
Noora Hirvonen \\ Oulun yliopisto \\ noora.hirvonen@oulu.fi \\ https://orcid.org/0000-0001-7577-3057
}

We report findings of the project Taking Health Information Behaviour into Account: implications of a neglected element for successful implementation of consumer health technologies on older adults (HIBA) based at Åbo Akademi University. The results stress that a key reason for digital health services (e-health) not being used or considered useful is that they are developed without fully considering how they align with the life-context and everyday-information behaviours of their intended users. Older adults' (50-70y) experiences of technologies and the information they convey vary and should be treated as two distinct facets of whether a particular service is found useful. Instead of focussing on specific systems, the emphasis of developing e-health services should be put on solving people's changing needs relating to their everyday challenges, well-being, and access to information they themselves find useful.

Asiasanat: terveyspalvelut, terveyskäyttäytyminen, informaatiokäyttäytyminen, sähköiset palvelut, ikääntyneet, aikuiset, käyttäjäkeskeinen suunnittelu, e-terveys

Artikkeli on lisensoitu Creative Commons Nimeä-EiKaupallinen-JaaSamoin 4.o Kansainvälinen -lisenssillä 


\section{Johdanto}

Erilaisia digitaalisia terveyspalveluita kuten potilasfoorumeja, sähköisiä potilasarkistoja, mobiileja terveyspalveluita ja omaseurantajärjestelmiä kehitetään ja otetaan lisääntyvästi käyttöön ympäri maailmaa. Odotukset niin palveluiden yksilöllisten kuin yhteiskunnallisten hyötyjen suhteen ovat korkeita. On kuitenkin tavallista, että palvelut eivät vastaa niille asetettuja tavoitteita. Palveluiden käyttö saattaa jäädä vähäiseksi tai hyödyt saavuttamatta. Yksi keskeisistä ongelmista on, että palveluita kehitetään huomioimatta niitä käyttävien kansalaisten päivittäistä elämää ja sitä, miten yksittäiset digitaaliset palvelut ovat vain pieni osa arjen laajempaa tiedonlähteiden ja digitaalisten ja ei-digitaalisten palveluiden kokonaisuutta. Kuten tietoa yleensä, myös terveystietoa haetaan, käytetään ja terveyttä hoidetaan samanaikaisesti käyttämällä monia eri lähteitä ja palveluita. Yksittäinen palvelu on käyttäjälle vain yksi monien muiden joukossa laajassa yksilön henkilökohtaisen terveystietokäyttäytymisen kentässä.

Tämän katsauksen tavoitteena on esitellä Suomen Akatemian rahoittaman tutkimusprojektin (hanke 287084) Hälsoinformationsbeteende $i$ e-hälsokontext: inverkan av ett negligerat element $i$ framgångsrik implementering av konsumentinriktade hälsoteknologier för äldre vuxna (lyhenne HIBA, suomennettuna Terveystietokäyttäytyminen e-terveyskontekstissa: laiminlyödyn tekijän vaikutus kuluttajasuuntautuneiden terveysteknologioiden menestyksellisessä toteuttamisessa) keskeisiä tuloksia. Samalla esittelemme lyhyesti yleisemmin ajankohtaista ikääntyvien terveystietokäyttäytymiseen ja digitaalisten terveyspalveluiden käyttöön liittyvää tutkimusta. Viisivuotisen projektin tavoitteena on ollut selvittää lähtökohtia sähköisten terveyspalveluiden kehittämiselle. Yksittäisten palveluiden tarkastelemisen sijaan, projekti on keskittynyt tutkimaan mikä tekee palveluista ymmärrettäviä, merkityksellisiä ja käyttökelpoisia ikääntyvien aikuisten päivittäisessä elämässä, kun huomioon otetaan se, miten he yleisesti ottaen etsivät, käyttävät ja hallitsevat terveyteen liittyvää tietoa.

HIBA-projekti pohjaa informaatiotutkimuksen alalla vakiintuneeseen, jo 1990-luvulla käynnistyneeseen yhteistyöhön terveystietoon liittyvien ilmiöiden tutkimuksessa. Åbo Akademissa ja Oulun yliopistossa toimivat tutkijat ovat osallistuneet lukuisiin monitieteisiin terveystietoon ja terveyden edistämiseen liittyviin tutkimushankkeisiin, ja vuonna 2008 perustettiin tutkimusryhmä Health Information Mastering, HIM-Oulu\&Åbo aihetta koskevan tutkimuksen ympärille. Vuosien 2014-2016 aikana TEKESin rahoittama monitieteinen oululaisin voimin toteutettu GASEL-hanke (2016) keskittyi ikääntyneiden omaan osallisuuteen ja vertaisverkostoon sekä 
räätälöityyn vuorovaikutteiseen ohjaukseen perustuvan hyvinvointipalvelukonseptin suunnitteluun. Åbo Akademin Informaatiotutkimuksen oppiaineessa tehtiin samaan aikaan ikääntyneisiin liittyvää terveystietokäyttäytymisen tutkimusta koskien muun muassa terveyskäyttäytymistä ja käsityksiä, terveystiedon lukutaitoa ja hallitsemista ja kirjastoja (esim. Eriksson-Backa, 2010, 2013; Eriksson-Backa \& Ek, 2015).

\section{Taustaa}

Digitaalisilla terveyspalveluilla tai e-terveyspalveluilla (englanniksi e-health services) viitataan tyypillisesti Internetin kautta välitettäviin terveyspalveluihin ja terveystietoon. Eysenbach (2001) huomauttaa lisäksi, että kyse ei ole vain teknologioista vaan myös asenteesta ja näkemyksestä parantaa terveydenhoitoa tieto- ja viestintäteknologiaa käyttämällä. E-terveyspalvelujen uskotaan edistävän sekä palvelujen käyttäjien että tuottajien pääsyä oleelliseen terveystietoon, parantavan hoidon laatua, vähentävän terveydenhuollon virheitä, ja lisäävän yhteistyötä (Kreps \& Neuhauser, 2010). Digitaalisten terveyspalveluiden kehittämisessä tärkeässä roolissa on myös terveydenhuollon asiakkaiden (potilaiden, kansalaisten) aktiivinen rooli oman terveytensä edistämiseen (Hyppönen et al., 2017; Kreps \& Neuhauser, 2010). Digitaalisiin terveyspalveluihin luetaan digitaaliset potilaskertomukset, mobiilit terveyspalvelut, telelääketiede ja muun muassa henkilökohtaisen terveysdatan kuten verenpaine- tai verensokeriarvojen kerääminen. Shawn ja kollegoiden luokittelun perusteella palvelut voidaan jakaa käden ulottuvilla oleviin (mukana kulkeva monitorointi, seuranta ja tieto), vuorovaikutteisiin viestintäpalveluihin ja terveyttä edistäviin digitaalisiin terveyspalveluihin (Shaw et al., 2017). Näitä palveluita on tutkittu laajalti, mutta erityisesti keskittyen niiden käytettävyyteen, palveluiden käyttötapoihin ja käyttöä helpottaviin ja haittaaviin tekijöihin (Hirvonen et al., 2020).

HIBA-projektissa digitaalisten terveyspalvelujen käyttöä on tarkasteltu keskittymällä tiettyyn kohderyhmään, ikääntyviin aikuisiin. Palveluiden käyttöä on lähestytty tietokäyttäytymisen näkökulmasta. Ikääntyvillä aikuisilla viitataan 50-70-vuotiaisiin erotuksena nuorempiin aikuisiin ja tätä vanhempiin ikääntyneisiin. Viidenkymmenen vuoden ikää käytetään ajoittain alaikärajana tutkimuksissa joiden kohderyhmää kutsutaan englanniksi termillä "older adults" (Muellmann et al., 2018). Yli 50-vuotiaiden terveydentila ja elämäntilanne poikkeavat tavallisesti monin tavoin sitä nuoremmista ikäryhmistä. Ikääntyvien suhde terveystietoon eroaa nuoremmista ja sen käyttö voi muuttua satunnaisesta jatkuvammaksi. Ruotsissa toteutetun 
kyselytutkimuksen perusteella ikäryhmiä vertailtaessa, nuoremmat kokivat terveydentilansa keskimäärin paremmaksi ja he olivat vähemmän huolestuneita omasta terveydestään kuin vanhemmat (Huvila et al., 2018). Yli 70vuotiailla geriatristen sairauksien ilmaantuvuus alkaa puolestaan kasvaa (Morley, 2017). Ikääntyvät eivät muodosta homogeenista joukkoa, mutta ryhmälle on yhteistä se, että he ovat pääsääntöisesti vielä mukana työelämässä, hiljalleen lähenemässä eläkeikää, eläköitymässä tai he ovat vasta eläköityneet. Kroonisten sairauksien riski ja esiintyvyys kohoaa kyseisessä ikäryhmässä (U.S. Department of Health and Human Services, 2020; Wildenbos et al., 2018) verrattuna nuorempiin, mutta ikääntyvät aikuiset ovat silti vielä pääsääntöisesti itsenäisiä ja elävät aktiivista elämää (Scharn et al., 2018). Toisin kuin monet vanhempien ikäluokkien edustajat, he ovat myös todennäköisesti käyttäneet tietokonetta työssään ja arkielämässään.

Ikääntyvät ovat merkittävä ikäryhmä digitaalisten terveyspalveluiden kehittämisen näkökulmasta useasta syystä. Aikaisempi tutkimus on osoittanut, että väestön vanheneminen johtaa digitaaliseen epätasa-arvoon. Ikääntyvät ovat nopeimmin kasvava tietokoneita ja Internetiä käyttävien ryhmä johon on usein aikaisemmin kuulunut myös ei-käyttäjiä (Cotten et al., 2012; Heart \& Kalderon, 2013). Ikäryhmässä ongelmia tuottaa sekä teknologian ja päätelaitteiden että niiden käytön puute (Chesser et al., 2015) ja lähemmin teknologian vieraus (Fischer et al., 2014), itseluottamuksen puute (Lee et al., 2011), motoriset ja kognitiiviset vaikeudet (Fletcher \& Jensen, 2015; Hemsley et al., 2018) sekä ikääntymiseen liittyvät psykologiset ja sosiaaliset muutokset (Wrzus et al., 2013). Terveyden lukutaidon (englanniksi health literacy) taso on myös useasti liitetty digitaalisten terveyspalvelujen käyttöön tai käyttämättömyyteen (Coughlin et al., 2018; Crameri et al., 2020; Paige et al., 2018). Myös ikääntyvien tietokäyttäytyminen - ymmärrettynä Wilsonin (2000) tapaan laajasti kaiken tietoon ja tiedonlähteisiin liittyvän inhimillisen käyttäytymisen kokonaisuutena - eroaa muista ryhmistä. Terveystiedon hankinta muuttuu intensiivisemmäksi ja mahdollisesti heikentyvä terveydentila tuottaa uudenlaisia tiedontarpeita. Myös perheen ja läheisten terveystiedon tarpeet ja niiden muutokset vaikuttavat tietokäyttäytymiseen. Ikääntyvillä harvoin enää asuu omia lapsia kotona, mutta omien ikääntyneiden vanhempien terveydentila saattaa luoda uusia tarpeita (Huvila et al., 2018).

HIBA-projektin tutkimustulokset täydentävät kuvaa ikääntyvistä ryhmänä, jossa nuoremmille aikuisille tyypilliset piirteet muuttuvat kohti ikääntyneille tyypillisiä piirteitä ja jossa selvästi opitaan ja omaksutaan myöhemmälle iälle jatkuvia toimintamalleja. Toisaalta muutos ei ole suoraviivainen. Erityisesti tietokäyttäytymisen ja terveystiedon lukutaidon suhteen ikääntyvien aikuisten tarpeet ja toiminta eroavat nuoremmista ja vanhemmista siinä, miten tietoa 
hankitaan ja käytetään. Tämä ei kuitenkaan tarkoita, että toiminta olisi laadullisesti huonompaa tai tehottomampaa (Huvila et al., 2018).

\section{Menetelmät}

HIBA-projekti keskittyi tutkimaan suomalaisten 50-70-vuotiaiden ikääntyvien aikuisten terveystietokäyttäytymistä, terveystiedon lukutaitoa (englanniksi health information literacy) ja käsityksiä digitaalisista terveyspalveluista. Tutkimuksissa käytettiin sekä laadullisia että määrällisiä menetelmiä. Projekti keskittyi ikäryhmään, jolle digitaalisten terveyspalveluiden aikaisempaa aktiivisemman käytön on esitetty olevan erityisen hyödyllistä ja joka jo nykyisellään käyttää palveluja suhteellisen aktiivisesti (Jormanainen et al., 2019; Mielonen et al., 2021) verrattuna muihin ikäryhmiin. Ikääntyvien osuus väestöstä on kasvamassa nopeasti ja terveyspalveluiden tarpeen voidaan olettaa lisääntyvän tulevaisuudessa juuri tässä ryhmässä (Huvila et al., 2016). Verrattuna ikääntyneisiin, ikääntyvien aikuisten pitempi jäljellä oleva eliniän odote merkitsee myös sitä, että digitaalisten terveyspalveluiden käytön vaikutusten voidaan olettaa olevan suurempaa juuri tässä ikäryhmässä (Nikou, 2015).

Projektin tutkimusta taustoitti sen alussa toteutettu systemaattinen kirjallisuuskatsaus. Katsauksen avulla koottiin yhteen aikaisempaa tutkimusta ikääntyvien aikuisten käsityksistä digitaalisista terveyspalveluista. Projektin puitteissa kerättiin myös uutta tutkimusaineistoa tekemällä fokusryhmähaastatteluita keväällä 2019 sekä toteuttamalla kansallinen postikyselytutkimus edustavalle otokselle suomen- ja ruotsinkielisiä 50-70-vuotiaita aikuisia kesällä 2019. Fokusryhmähaastattelututkimus suunniteltiin systemaattisen kirjallisuuskatsauksen tulosten ja tutkimusryhmän aikaisempien tutkimusten havaintojen perusteella. Haastattelun tuloksia hyödynnettiin vastaavasti kyselytutkimuksen suunnittelemisessa. Esimerkkinä ja vertailukohtana digitaalisista terveyspalveluista projektissa käytettiin valtakunnallista Omakanta-palvelua, jonka - toisin kuin kunnallisten, alueellisten tai yksityisten palveluntuottajien digitaalisten terveyspalveluiden - voitiin olettaa olevan tuttu ympäri maan.

Projektissa tehtiin lisäksi yhteistyötä ruotsalaisten DOME-konsortion (https://domeconsortium.org) tutkijoiden kanssa analysoiden sikäläisten ikääntyvien aikuisten näkemyksiä ja kokemuksia digitaalisten terveyspalveluiden käytöstä kyselyaineistojen avulla. Tutkimusta tukivat myös aikaisempien tutkimushankkeiden piirissä kerättyjen aineistojen analyysi, jota tehtiin yhteistyössä kyseisissä hankkeissa työskennelleiden tutkijoiden kanssa 
(esimerkiksi Terveystiedon käytännöt ja vaikuttavuus - HeIP https://www. oulu.fi/informaatiotutkimus/content/tutkimuksen-painoalat ja GASEL https://www.oulu.fi/gasel/ -tutkimushankkeet). Lisäksi HIBA-projektissa toteutettiin yhteistyössä Diabetesliiton kanssa kyselytutkimus Tyypin 2 diabeteksen riskitestin käyttäjille. Tutkimusyhteistyön kautta projektille avautui mahdollisuuksia tarkentaa fokusryhmähaastattelun ja kansallisen kyselytutkimuksen aihepiirejä ja tutkimuskysymyksiä ja täydentää analyysia laajentamalla näkökulmaa ja tutkimuksen kattavuutta. Kuvio 1 kuvaa projektin lähestymistapaa ja osatutkimusten suhdetta toisiinsa.

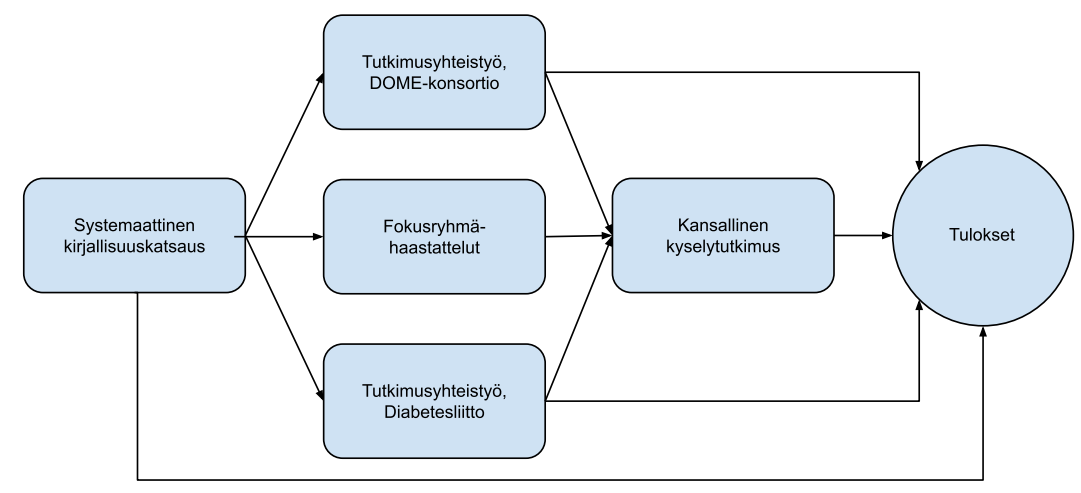

Kuvio 1: HIBA-projektin metodologinen lähestymistapa, osatutkimukset ja yhteistyö.

\section{Tuloksia}

\section{Aikaisempi tutkimus keskittyy vahvasti käytettävyyteen}

HIBA-projektissa toteutetun systemaattisen kirjallisuuskatsauksen (Hirvonen et al., 2020) tulokset osoittavat, että aikaisempi digitaalisten terveyspalveluiden tutkimus on keskittynyt paljolti järjestelmien tekniseen käytettävyyteen. Sen sijaan palveluiden käytännöllisyyttä ja hyödyllisyyttä käyttäjille ja sitä, miten hyvin palvelut vastaavat käyttäjien jokapäiväisiin tarpeisiin, on tutkittu vähemmän. Aikaisempi tutkimus on lähestynyt digitaalisten terveyspalveluiden käyttöä lukuisista eri näkökulmista ja eri menetelmin. Tyypillisiä tutkittuja teemoja ovat muiden muassa palveluiden käyttötavat, käyttöä helpottavat ja haittaavat tekijät ja käytön myönteiset ja kielteiset seuraukset. Kirjallisuuskatsauksessa havaittiin myös yhteys käytetyn tutkimusmenetelmän ja raportoitujen tulosten välillä. Erityisesti määrällisissä kyselytutkimuksissa 
raportoitiin tyypillisesti positiivisia tuloksia sen sijaan, että niissä olisi tuotu esiin palveluiden käytössä havaittuja ongelmia tai käytön esteitä. Katsaukseen sisältyneet laadulliset tutkimukset kuitenkin osoittivat, että digitaalisten terveyspalvelujen käyttöön voi liittyä negatiivisia kokemuksia tai odotuksia esimerkiksi yksityisyyden menettämisestä ja eristäytymisestä. Yleisellä tasolla katsauksen havaintojen voidaan katsoa heijastavan myös suomalaista alan tutkimusta. Tyypillisiä tutkimusaiheita ovat olleet muun muassa teknologian hyväksyntä ja tietotekniset valmiudet (Mielonen et al., 2021) ja järjestelmien ja palvelujen käyttö ja käytettävyys (Hyppönen et al., 2018; Jormanainen et al., 2019; Lämsä et al., 2017; Taipale \& Hänninen, 2018). Kansalaisten yleisten tarpeiden ja kokemusten lisäksi tutkimuksissa on selvitetty myös ammattilaisten kokemuksia (esim. Kauppinen et al., 2017), palvelujen käyttökokemuksia esimerkiksi työterveyshuollossa (esim. Nissinen et al., 2018) ja käyttökokemusten tiettyjä osa-alueita kuten turvallisuuteen liittyviä huolia (esim. Palojoki et al., 2016).

\section{Ikääntyvillä tiedontarpeet muuttuvat}

Tutkimus, jossa tarkasteltiin omia potilaskertomuksia kotiin tilanneiden ruotsalaisten ikääntyvien aikuisten toiveita verrattuna muihin ikäryhmiin ja tarpeita potilaskertomustiedon ja e-terveyspalveluiden suhteen osoitti, että eläkeiän kynnys on elämänvaihe, jossa terveystiedon tarpeet kasvavat ja suhde terveyteen, terveydenhoitoon ja terveystietoon muuttuu (ks. esim. Huvila et al., 2018). Verrattuna nuorempiin, ikääntyvät etsivät enemmän terveystietoa verkosta ja lukivat omaa potilaskertomustaan saadakseen yleiskuvan omasta terveydentilastaan. Toisaalta verrattuna ikääntyneisiin, ikääntyvien aikuisten luottamus omaan kykyynsä ymmärtää potilaskertomustekstiä oli heikompi. Yleisesti ottaen verrattuna muihin ikäryhmiin, ikääntyvät luottivat myös vähemmän kykyynsä ymmärtää terveyteen liittyvää Internetissä olevaa tietoa.

Vaikuttaa myös siltä, että tarjolla olevan informaation ajantasaisuus ja koherenssi ovat käyttäjille tärkeitä (Eriksson-Backa et al., 2021). Potilaskertomustiedon suhteen ikääntyneiden ja ikääntyvien aikuisten tiedontarpeet keskittyvät nuorempia enemmän terveydentilan yleiseen seurantaan yksityiskohtien sijaan. Tosin verrattaessa eri tutkimusten tuloksia toisiinsa, digitaalista potilasarkistoa käytettäessä yleistietoa saattavat sittenkin hakea useimmiten nuoremmat käyttäjät (Huvila et al., 2018, vrt. 2021). Tiedon oikeellisuuden tarkastamisen suhteen ikäryhmien välillä ei ole merkittäviä eroja (Huvila et al., 2018). Tulosten perusteella vaikuttaa kuitenkin siltä, että tässäkin suhteessa digitaalista palvelua käytettäessä nuoremmat ovat vanhempia aktiivisempia (Huvila et al., 2021). 
HIBA-projektissa toteutetun systemaattisen katsauksen perusteella (Hirvonen et al., 2020) digitaalisilla terveyspalveluilla on havaittu olevan myös kielteisiä vaikutuksia. Sellaisia ovat muun muassa ahdistuneisuus ja stressi, ihmiskontaktien puute ja vähentynyt kanssakäyminen terveydenhuoltohenkilökunnan kanssa, yksityisyyden suojaan liittyvät ongelmat tai niiden pelko ja huoli palvelun epäkuntoon menemisestä. Lisäksi tuomitseva kieli ja äänensävy, luottamuksen puute palvelun välittämään tietoon, tiedon subjektiivinen tulkitseminen ja sisällössä olevat virheet on koettu kielteisesti eri tutkimuksissa. Myös uhka datan katoamisesta, palvelun käyttämiseen kuluva aika ja tekniset viat voidaan kokea ongelmallisina.

\section{Digitaalisten terveyspalveluiden käyttö, käytännöllisyys ja hyödyl- lisyys}

Systemaattisen katsauksen perusteella ikääntyvät aikuiset käyttävät digitaalisia terveyspalveluita viestintään, tiedonjakamiseen, palautteen hankkimiseen ja valmistautuessaan terveydenhuoltokäynneille (Hirvonen et al., 2020). Nuorempiin aikuisiin verrattuna, tiedon jakaminen vaikuttaisi olevan tavallisempaa vanhempien keskuudessa (Nurgalieva et al., 2020). Palvelut tukevat ikääntyvien mahdollisuutta asettaa itselleen tavoitteita, seurata oireita, suunnitella omaa toimintaansa, asettaa muistutuksia sekä tarjota suosituksia ja informaatiota. Tämän lisäksi digitaaliset terveyspalvelut voivat olla hyödyksi niin henkilökohtaisten kuin lähiomaisten terveyttä koskevien tietojen hallinnassa (Hirvonen et al., 2020), mikä on kenties vähemmän ilmeinen näkökulma. HIBA-projektin kansallista Omakantaa koskevassa osatutkimuksessa fokusryhmähaastattelujen osalllistujat kuvailivat käyttäneensä palvelua muun muassa reseptitietojen tarkasteluun ja uusimiseen, elinluovutustestamentin tekemiseen, valmistautuakseen lääkärikäyntiin ja tarkistaakseen lääkärikäynnin tai testin jälkeen sen tuloksia ja käynnistä kirjattuja tietoja. Palvelua käytettiin myös yhdessä verkkotiedonhaun kanssa terveystiedon hankkimiseen (Eriksson-Backa et al., 2021).

Projektin osatutkimuksessa, jossa analysoitiin odotuksia digitaalisten terveyspalveluiden hyödyllisyydestä Uppsalan läänissä Ruotsissa kerätyn kyselyaineiston perusteella, ikääntyvät olivat, verrattuna nuorempiin ja ikääntyneisiin, vähemmän kiinnostuneita viestimään terveydenhoitohenkilökunnan kanssa sähköpostitse, käyttämään verkossa olevaa terveystietoa ja luottivat siihen vähemmän. Toisaalta ikääntyvät kuitenkin hankkivat nuorempia enemmän terveystietoa verkosta (Huvila et al., 2018).

Vaikka aiempi tutkimus on paljolti keskittynyt käytettävyyteen, senkin perusteella digitaaliset terveyspalvelut koetaan tyypillisesti hyödyllisiksi ja 
niihin ollaan voittopuolisesti tyytyväisiä (Hirvonen et al., 2020). Palvelut voivat parantaa tietämystä terveyteen liittyvistä asioista ja kykyä käsitellä terveyteen liittyvää tietoa, auttaa omasta terveydestä huolehtimisessa, päätöksenteossa, parantaa viestintää terveydenhuollon ammattilaisten kanssa, hoidon jatkuvuutta ja auttaa ymmärtämään asiantuntijoiden näkemyksiä. Palvelut voivat tarjota ja välittää myös emotionaalista tukea, positiivisia tunteita, luottamusta ja itseluottamusta sekä tukea hallinnan, voimaantumisen ja turvallisuuden tunteita (Hirvonen et al., 2020; ks. myös Eriksson-Backa et al., 2021). Palveluiden koettua hyödyllisyyttä voi lisätä muun muassa tiedon helpompi saatavuus yhdestä paikasta, käytön helppous, mahdollisuus seurata omaa terveydentilaa pitkäjänteisesti ja palvelusta riippuen mahdollisuus tarkistaa kuka on tarkastellut käyttäjän potilastietoja (Eriksson-Backa et al., 2021; ks. myös Huvila et al., 2018).

Digitaalisten terveyspalveluiden käytön seurauksena on havaittu, että ikääntyvät aikuiset muun muassa hakevat lisätietoa, hakeutuvat terveydenhuollon piiriin ja hankkivat apua oman terveystietonsa hallintaan. Palvelut voivat myös edistää halua muuttaa terveyskäyttäytymistä ja olla yhteydessä käyttäytymisen tosiasialliseen muutokseen (Hirvonen et al., 2020). Projektissamme toteutetun empiirisen eri ikäryhmiä vertailevan tutkimuksen perusteella ikääntyvillä aikuisilla ja ikääntyneillä digitaalisten terveyspalvelujen käyttö vaikuttaisi liittyvän erityisesti konkreettisiin tarpeisiin ymmärtää omaa terveydentilaansa kun nuorempien kohdalla motivaattorina toimii todennäköisemmin yleinen mielenkiinto (Huvila et al., 2021). Erityisesti terveystiedon lukutaidon ja aktiivisemman henkilökohtaisesta terveydestä huolehtimisen tärkeys ja sen tukeminen digitaalisten terveyspalvelujen kautta korostuu tutkimuksemme mukaan nimenomaan ikääntyvillä, joiden terveydentilassa alkaa esiintyä yksilöille itselleen uusia ja kenties yllättäviäkin vanhenemiseen liittyviä muutoksia. Tiedontarve muuttuu ja lisääntyy ja ikääntyneillä sekä digitaalisten terveyspalveluiden että niiden käytön hyödyt ovat jo todennäköisesti ilmeisempiä kuin nuoremmilla, mutta oppimisen ja tapojen muuttamisen kannalta tällöin ollaan jo myöhään liikkeellä (Huvila et al., 2018).

\section{Digitaalisten terveyspalveluiden käyttöä estäviä tekijöitä}

Lukuisat määrälliset kyselytutkimukset, joissa on verrattu informaatiolukutaitoa (englanniksi information literacy), terveystiedon lukutaitoa ja teknologioiden käyttöä eri ikäryhmissä osoittavat, että ikääntyvät aikuiset pitävät terveystietoa tärkeänä, mutta tiedon löytämistä ja ymmärtämistä vaikeana (Hirvonen et al., 2020). HIBA-projektin puitteissa toteutettujen haastattelu- ja kyselytutkimusten alustavat, ja jo julkaistut, tulokset viittaavat samaan. 
Mitä hyödyllisemmäksi palvelu ja sen sisältö koetaan kokonaisuudessaan, sitä valmiimpia ikääntyvät ovat käyttämään palvelua, edellyttäen, että se koetaan myös teknisesti ja sisällöllisesti riittävän ymmärrettäväksi ja helposti lähestyttäväksi (ml. Eriksson-Backa et al., 2021).

Eräs keskeisistä digitaalisten terveyspalveluiden käyttöön, niiden sisällön ymmärtämiseen ja lähestyttävyyteen liittyviä vaikeuksia ennakoivista tekijöistä on koettu puutteellinen terveystiedon lukutaito. Ikääntyvillä, jotka pitävät omaa terveystiedon lukutaitoaan heikkona, on usein vähemmän kokemusta mobiiliteknologioiden kuten älypuhelinten käytöstä. He myös usein suhtautuvat näihin teknologioihin kielteisesti. Vastaavasti positiivinen asenne mobiiliteknologioiden käyttöön liittyy paremmaksi koettuun terveystiedon lukutaitoon (Enwald et al., 2018). Toisaalta on havaittu, että terveystiedon lukutaito ei välttämättä parane vaan pikemminkin muuttuu iän myötä suhteessa eri ikävaiheisiin liittyviin haasteisiin (Huvila, Hirvonen, et al., 2019). Aikaisemmin toteutetussa ja HIBA-projektissa analysoidussa ikääntyneille (65-79-vuotiaille) suunnatussa kyselytutkimuksessa havaittiin myös, että luottamus omiin kykyihin ymmärtää ja hallita terveystietoa (englanniksi niin sanottu health information seeking self-efficacy) ja huolehtia omasta terveydestään liittyy vahvasti sekä parempaan terveydentilaan että aktiiviseen tiedonhankintakäyttäytymiseen (Eriksson-Backa et al., 2018). Ikääntyvien aikuisten itseluottamus omiin kykyihinsä ymmärtää terveystietoa saattaa myös olla muita ikäryhmiä heikompi (Huvila et al., 2018; Huvila, Moll, et al., 2019). Ruotsalaisten ikääntyviä koskevassa osatutkimuksessamme, jossa selvitettiin eri ikäryhmien mieltymyksiä lisätiedon hankkimiseksi mikäli he eivät ymmärrä itseään koskevia potilaskertomustietoja, selvisi, että ikääntyvät turvautuvat muita ikäryhmiä useammin potilaskertomustietoihin liittyvään puhelinpalveluun kuin kysyvät asiasta tutuilta tai perheenjäseniltä (Huvila et al., 2019).

Aikaisempien tutkimusten mukaan digitaalisten terveyspalveluiden käyttöä haittaavia tekijöitä ovat muun muassa tekniset ongelmat, kokemuksen, itseluottamuksen puute, tiedon tai päätelaitteen menettämisen tai rikkoutumisen pelko, hinta, kognitiiviset ja terveyteen liittyvät vaikeudet, ajan puute ja kokemus vaivalloisuudesta. Myös tarve turvautua ulkopuoliseen apuun, yleinen negatiivinen asenne teknologioihin sekä tietoturvaan ja yksityisyyden suojaan liittyvät huolet vähentävät näiden palveluiden käyttöä (Hirvonen et al., 2020). Erityisesti vanhimmilla käyttäjillä ongelmat vaikuttavat liittyvän enemmän teknologiaan kuin sisällön ymmärtämiseen (Huvila et al., 2021). Omakantaa koskevassa haastatteluihin perustuvassa tutkimuksessamme havaittiin myös järjestelmään kirjautumisen ja palvelukatkojen aiheuttavan toisinaan ongelmia (Eriksson-Backa et al., 2021). Käyttöä voivat estää tai 
vaikeuttaa myös lääketieteellisen terminologian ja kielen vaikeaselkoisuus. Lähiomaisia autettaessa ikärajat ja tiedonjakamiseen liittyvät estot vaikeuttavat palvelun käyttöä. Kuten aikaisemmassakin tutkimuksessa, haastateltavat olivat huolissaan myös palvelun tietoturvallisuudesta ja yksityisyyden suojasta, virheellisistä tiedoista ja mahdollisuudesta törmätä kielteiseen tai pelottavaan omaa terveydentilaa koskevaan tietoon ennen lääkärikäyntiä. Digitaaliset terveyspalvelut ja pääsy omiin potilastietoihin aiheutti myös joillakin turhautumista siihen, että hoitohenkilökunta ei ollut tutustunut potilastietoihin ennen käyntiä. Olennainen ongelma oli myös se, että useammat terveydenhuoltopalveluiden tarjoajat, kuten kunnat, sairaanhoitopiirit ja yksityiset tahot ylläpitävät samantyyppisiä, osittain päällekkäisiä palveluita, jotka toimivat osittain eri tavoin ja voivat aiheuttaa hämmennystä (Eriksson-Backa et al., 2021).

Havaintoja ikääntyvien aikuisten terveystietokäyttäytymisestä on hyödyllistä verrata myös yleisiin ikäryhmälle tyypillisiin toimintamalleihin. Aktiivisten, laaja-alaisten ja oma-aloitteisten tiedonhankkijoiden aktiivisuus myös heidän muussa toiminnassaan viittaa Matteus-vaikutukseen (ErikssonBacka \& Nguyen, 2020) eli positiivisten toimintatapojen kasaantumiseen tietyille ihmisille. Esimerkiksi krooninen sairaus on usein merkittävä tekijä, joka vaikuttaa terveystietokäyttäytymiseen (ks. Rexhepi et al., 2020), mutta se ei kuitenkaan välttämättä muuta varsinaista terveyskäyttäytymistä. Päinvastoin joissakin tapauksissa terveeksi itsensä kokevat saattavat olla valmiimpia muuttamaan omaa toimintaansa (Eriksson-Backa \& Nguyen, 2020, p. 20; Nguyen et al., 2018). Tämä viittaa siihen, että ihmiset eivät aina tee samantyyppisiä johtopäätöksiä samankaltaisten ongelmien tai kokemusten perusteella. Siten myös toimintamallit ja niiden muutokset eri ikäryhmissä eroavat toisistaan (esim. Huvila et al., 2018, vrt. 2015). Vaikka ikäryhmät muodostavatkin hyödyllisen tavan erotella erilaisia käyttäjiä toisistaan, on syytä muistaa myös, että ikääntyvät ei ole yhtenäinen ryhmä vaan sen sisällä on suurta vaihtelua niin asenteissa, toiveissa kuin taidoissakin (Eriksson-Backa et al., 2018).

\section{Digitaalisten terveyspalveluiden käyttöä edistäviä tekijöitä}

Projektin tulokset suomalaisten ikääntyvien aikuisten käsityksistä Omakanta-palvelusta osoittavat, että ikääntyvien huolenaiheet ja järjestelmän käyttöä estävät syyt koostuvat sosiaalisten, teknisten ja informaatioon liittyvien tekijöiden yhdistelmistä ja riippuvat järjestelmän tarjoamasta tietosisällöstä (Eriksson-Backa et al., 2021). Eri tutkimusten tuloksia vertailtaessa vaikuttaa myös siltä, että digitaalisia terveyspalveluita kehitettäessä ja 
arvioitaessa olennaista on huomioida millaista sisältöä ne tarjoavat. Käytön helppous ja sisällön ymmärrettävyys, palvelun tuoma lisäarvo, omat tarpeet ja kiinnostuksen kohteet sekä sisällön ja toimintojen relevanssi edistävät yleisesti ottaen digitaalisten terveyspalveluiden käyttöä. Omat taidot, palveluiden houkuttelevuus, tarvittavien päätelaitteiden olemassaolo, aikaisempi kokemus, mahdollisuus saada apua ja tieto palvelun olemassaolosta voivat myös helpottaa palveluiden käyttöä (Hirvonen et al., 2020). Tässä suhteessa tulokset ovat yhteneväisiä toisaallakin esitetyn ajatuksen suhteen, että ikääntyviä voi olla hyödyllistä ohjata käyttämään palveluita aikaisempaa varhaisemmassa elämänvaiheessa (Mielonen et al., 2021).

Projektimme tutkimustulokset viittaavat lisäksi siihen, että palveluiden käyttöä voi edistää parantamalla niiden sisältöä ja toiminnallisuutta. Puuttuvien tietojen täydentäminen ja tarkemman tiedon tarjoaminen, muistutustoiminnot, laajempi terveyteen liittyvien tietojen tallentaminen yhteen palveluun, mahdollisuus täydentää tietoja, ottaa yhteyttä ja antaa palautetta, linkit lisätietoon, mahdollisuus muokata palvelun ulkoasua, järjestelmien yhteiskäyttö ja yhdenmukaisempi tietosisältö koettiin Omakantaa koskevassa tutkimuksessa ominaisuuksiksi, joita kyseisessä palvelussa olisi voitu parantaa (Eriksson-Backa et al., 2021). Omaa itseä koskeva terveystieto, esimerkiksi potilaskertomus, saattaa olla palvelun käyttäjän näkökulmasta huomattavasti helpommin lähestyttävä kuin yleinen terveysinformaatio (esim. Enwald et al., 2018; vrt. Huvila et al., 2018). Tämä voi selittää myös miksi lääketieteellisen terminologian ymmärtämisessä on havaittu eroja eri tutkimuksissa (esim. Enwald et al., 2016; Huvila et al., 2015, 2018). Jos termit ovat tuttuja ja liittyvät omaan sairaushistoriaan tai ne esiintyvät tekstissä, jossa kuvaillaan diagnooseja tai hoitotoimia, joissa potilas itse on ollut osallisena, on luonnollista, että niitä on helpompi ymmärtää kuin jos niihin törmää ilman vastaavaa asiayhteyttä.

\section{Tietokäyttäytymisen ymmärtäminen palvelu- ja järjestelmä- suunnittelun apuna}

Terveystietoon ja digitaalisiin terveyspalveluihin liittyvien kysymyksenasettelujen kautta projektin puitteissa on lähestytty myös laajemmin tietokäyttäytymisen tutkimuksen ja järjestelmä- ja palvelusuunnittelun välistä kuilua. Olemme pohtineet sen syitä ja mahdollisia tapoja lähentää tutkimusalueita keskenään (Huvila, Enwald, Eriksson-Backa, et al., 2019; Huvila et al., 2021). Vertailu eri tieteen- ja käytännön alojen välillä osoittaa, että kapeat ja teknologiaan keskittyvät tutkimus- ja toiminta-asetelmat eivät ole tyypillisiä vain terveystietoon liittyvissä kysymyksissä. Tietokäyttäytymisen 
ja arkipäiväisten teknologioiden käytön rajapintojen tutkiminen ja vertaileminen eri yhteyksissä voikin tästä syystä tuottaa hyödyllistä tietoa siitä, miten tulevaisuuden järjestelmiä ja palveluita voidaan suunnitella vastaamaan paremmin niiden käyttäjien tarpeita ja toiveita. Samasta syystä järjestelmäja palvelusuunnittelun tukemiseksi terveydenhuollon tapaisissa konteksteissa on hyödyllistä pohtia laajemmin tiedonhankintaan ja teknologioiden käyttöön liittyvien ongelmien ja toiveiden suhdetta ikään ja elämäntilanteeseen. Myös tietosisältöjen räätälöintiä esimerkiksi terveystiedon lukutaidon koettu taso huomioiden voidaan harkita (ks. esim. Enwald, 2013). Eri aloilla käytettävä "kieli" voi myös toimia esteenä eri alojen yhteistyölle ja lähtökohtien ja erilaisten mahdollisuuksien ymmärtäminen voi myös avartaa yhteisen ymmärryksen löytymistä (Enwald, 2020).

Vastoin yleistä käsitystä tiedonhankintaan liittyvien teknologioiden käyttöä koskevat ongelmat tuskin katoavat nykynuorten vanhetessa vaikka niiden voikin olettaa lieventyvän ainakin jossakin määrin (Charness \& Boot, 2009; Wandke et al., 2012). HIBA-projektin tulokset antavat viitteitä siitä, että eri elämänvaiheissa haasteet ja ongelmat ovat erilaisia. Nuorten aikuisten kohdalla ongelmat saattavat kohdistua teknologiaa enemmän vaikeasti omaksuttavaksi koettuun terveystietoon kun taas vanhemmiten teknologioihin liittyvät ongelmat korostuvat terveystietoon liittyvien vaikeuksien rinnalla (Huvila, 2020). Mahdollinen selitys voi olla se, että nuorempana tiedonhankinnan tekniset tavat eivät ole vakiintuneet samaan tapaan kuin vanhemmiten ja kokemusta terveystiedonhankinnasta ja erilaisesta itselle relevantista terveystiedosta on vähemmän. Toisaalta vaikuttaisi siltä, että tietyt tavat hankkia tietoa saattavat olla hyvinkin sukupolvisidonnaisia. Tällaisia voivat olla esimerkiksi ikääntyvien suosima puhelimen käyttö soittamiseen ja nuoremmilla verkkotiedonhakuun (Huvila et al., 2019) - tosin niin, että nykynuorten ikääntyessä heidän nykyiset tiedonhankintatapansa saattavat samalla tavalla 'lukittua' vastaamaan tämän hetken tilannetta ilman että ne mukautuvat tulevaisuudessa muuttuviin tiedonhaun tapoihin (Huvila, 2020).

Kokonaisuudessaan HIBA-projektin tulokset vahvistavat näkemystä siitä, että ikääntyvien terveystietokäyttäytyminen olisi syytä huomioida digitaalisten terveyspalveluiden suunnittelussa laajemmin ja aikaisempaa enemmän. Tietokäyttäytymisen parempi ymmärtäminen auttaa näkemään yksittäisten palveluiden käytön osana käyttäjien laajempaa tiedonhankintaa ja -käyttöä (Hirvonen et al., 2020; Huvila et al., 2021; myös Avdagovska et al., 2020). Yksittäiselle digitaaliselle palvelulle on usein vaihtoehtoja. Niiden suosimiseen saattaa olla monia syitä ja yksittäisen palvelun suhteen monesti käypä vaihtoehto on myös sen käyttämättä jättäminen. Tietokäyttäytymisen kannalta keskeistä on myös se, että käyttäjän näkökulmasta palvelun hyödyl- 
lisyys riippuu sekä teknisen toteutuksen että sisällön koetusta hyödyllisyydestä. Siinä missä näitä usein tutkitaan yhdessä erottelematta niitä selvästi toisistaan, teknisesti hyvä palvelu saattaa vaikuttaa huonolta vain käyttäjänäkökulmasta epätarkoituksenmukaisen sisältönsä vuoksi tai käyttäjän kannalta sisällöltään käyttökelpoinen palvelu saattaa jäädä käyttämättä huonon tai epätarkoituksenmukaisen teknisen toteutuksen takia. Tekniset ja sisältöön liittyvät vaikeudet, toiveet ja käyttöä edistävät näkemykset myös vaihtelevat niin iän, kuin epäilemättä myös muiden tekijöiden, myötä. Tästä syystä teknologiaan ja sisältöön liittyviä näkökulmia olisikin syytä tarkastella rinta rinnan mutta silti erillisinä tekijöinä palveluja suunniteltaessa, kehitettäessä ja arvioitaessa (Huvila, 2020; Huvila et al., 2021). Tätä tarkoitusta varten HIBA-projektin yhteistyössä ruotsalaiskollegoiden kanssa esittämä Orlikowskin ja Gashin (1994) suositun teknologisten viitekehysten teoriaan laajentaminen tiedollisilla viitekehyksillä (Huvila et al., 2021). Tämä laajennettu viitekehysten teoria saattaa osoittautua jatkossa hyödylliseksi tavaksi jäsentää sisältöihin ja teknologiaan liittyvien käsitysten eroja ja yhtymäkohtia.

Tietokäyttäytymisen ja -käytäntöjen korostaminen palvelujen käytön taustalla nostaa etusijalle käyttäjän konkreettisen toiminnan oletettujen tai itsearvioitujen taitojen ja mieltymysten sijaan. Aikaisemmalle tutkimukselle on tyypillistä keskittyminen käyttäjien mielipiteisiin käytön ja taitojen mittarina vaikka onkin ilmeistä, että monissa tapauksissa käytetyt mittarit ja kysymykset mittaavat lähinnä käyttäjien yleistä itseluottamusta todellisen käyttäytymisen tai kykyjen sijaan (vrt. esim. Eriksson-Backa et al., 2018). Näin ollen palveluiden räätälöimisen apuna voisi tulevaisuudessa olla hyödyllistä käyttää muun muassa iän ja terveydentilan lisäksi toisaalta muun muassa käyttäjien terveystiedonhankkimisen itseluottamuksen (eng. health information seeking self-efficacy) kaltaista mittaria (Eriksson-Backa et al., 2018) ja toisaalta taitojen ja ymmärtämisen mittaamista ja arviointia.

Toisaalta tyypillistä on myös olettaa, että kyvyt ja tarpeet muuttuvat jokseenkin suoraviivaisesti sen sijaan, että eri ikäryhmissä tarpeet ja toiveet määräytyvät kullekin ikäryhmälle tyypillisten elämäntilanteiden ja tarpeiden mukaisesti, ne muuttuvat yksilöllisesti ja muuttavat terveystietokäyttäytymistä ja tiedontarpeita eri tavoin. Nuoremmalla iällä opitut taidot ja tavat kantavat myöhemmälle iälle vain jos ne ovat jatkossakin tarkoituksenmukaisia (Huvila et al., 2018). Palvelujen ymmärtäminen osana käyttäjien arkipäivää helpottaa niiden sovittamista osaksi käyttäjien elämää, ja olemassa olevien palvelujen käyttämättömyyden syiden paremman ymmärtämisen kautta mahdollisuudet edistää uusien käyttäjänäkökulmasta aiempaa tarkoituksenmukaisempien palveluiden kehittäminen helpottuu. HIBA-projektin näkökulma korostaa palvelujen hyödyllisyyden (eng. usefulness) merkitystä 
käytettävyyden (englanniksi usability) sijaan (Huvila, Enwald, Hirvonen, et al., 2019) ja auttaa ymmärtämään miksi toisinaan teoriassa hyvät palvelut koetaan jokapäiväisen elämän näkökulmasta hyödyttömiksi (Huvila et al., 2021).

\section{Loppupäätelmiä}

HIBA-projektin tulokset korostavat ihmisten tietokäyttäytymisen, sosioekonomisen elämänpiirin ja teknologioiden välisiä yhteyksiä ja tarvetta tarkastella näitä tekijöitä kokonaisuutena. Palveluiden käyttäjien käyttäytymisen ja käytänteiden ja palveluiden konkreettisen hyödyllisyyden ymmärtäminen on keskeistä olemassa olevien palveluiden menestyksekkäässä kehittämisessä ja uusien suunnittelussa. Tutkimustulokset viittaavat siihen, että ikä on hyödyllinen tapa eritellä terveystietokäyttäytymisessä tapahtuvia muutoksia. Ikää ei kuitenkaan ole syytä käyttää niinkään osoituksena siitä, että tietyissä ikävaiheissa jokaisen yksilön toimintamallit muuttuisivat samankaltaiseen suuntaan vaan pikemminkin siitä, että ihmisillä on tietyissä elämänvaiheissa samantapaisia ongelmia ja haasteita, joihin he reagoivat eri tavoilla. Projektin tulosten perusteella voidaan todeta, että 50-70-vuotiaita voitaisiin aikaisempaa enempää ohjata ja tukea nimenomaan ikääntyvinä - yksilöinä, jotka ikääntyvät sen sijaan että olisivat nuoria, vanhoja tai jotakin siltä väliltä. Sen sijaan, että ikääntyviä käsitellään nykyhetkessä joko kykenevinä ja osaavina tai vähemmän kykenevinä ja osaavina yksittäisten palveluiden käyttäjinä, heitä olisi hyödyllisempää lähestyä terveydestään nuorempiaan hiljalleen lisääntyvästi ja eri tavalla kiinnostuneina yksilöinä. Lisäksi olisi tärkeää ohjata heitä kohti uutta heille todennäköisesti lähitulevaisuudessa tarpeellista tietoa ja käyttökelpoisempia palveluita. Yleisemmin projektin tutkimustulosten perusteella vaikuttaa siltä, että laajempi kysymys tiedon ja informaatiosisältöjen, eri järjestelmien ja palveluiden, sekä terveyden ja iän välisestä suhteesta kaipaa lisää selvittämistä.

Ikääntyvien digitaalisten terveyspalveluiden käyttöä on syytä tutkia lisää myös jatkossa ja tähänastisia tuloksia soveltaa käytäntöön mahdollisuuksien mukaan sekä uusia että vanhoja palveluita kehitettäessä. Sekä tutkimusta että palvelujen vertailua ja kehittämistä vaikeuttaa palveluiden suuri kirjo ja erilaisten tutkimusasetelmien suuri määrä. Tässä suhteessa hyödyllistä olisi epäilemättä muun muassa jo tehtyjen tutkimusten toistaminen eri palvelujen ja käyttäjäryhmien kesken sekä erityisesti tietokäyttäytymisen suhteen, terveystietokäyttäytymiseen liittyvien tutkimusasetelmien järjestelmällinen kehittäminen ja hyödyntäminen osana olemassa olevien palvelujen rakentamista ja uusien kehittämistä. Digitaalisten terveyspalveluiden hyödyt, arvo ja 
käyttökelpoisuus eivät ole järjestelmien ja ohjelmistojen ominaisuuksia vaan tekijöitä, jotka rakentuvat järjestelmien ja niiden eri käyttäjien vuorovaikutuksessa. Tästä syystä perinteiset teknologioiden ja teknisten järjestelmien arvioimiseen, hyväksymiseen ja käyttöönottamiseen keskittyvät, edes käyttäjälähtöiset, teoriat, mallit ja menetelmät (ks. myös Harst et al., 2019) eivät välttämättä ole käyttökelpoisimpia palveluiden kokonaisvaltaisessa tarkastelussa. Jatkossa huomiota tulisikin kiinnittää aikaisempaa huomattavasti enemmän ihmisten muuttuvien inhimillisten tietoon ja toimintaan liittyvien tarpeiden ratkaisemiseen ja sihen, miten olemassa ja kuviteltavissa olevat palvelut ja järjestelmät yhdessä voivat auttaa yksilöitä erilaisissa ja muuttuvissa elämäntilanteissa. Digitaalisten terveyspalveluiden kohdalla keskeisiä eivät ole ainoastaan teknisen järjestelmän ominaisuudet, käytettävyys tai edes käyttökelpoisuus vaan se, miten niiden välittämä terveyteen liittyvä tieto tosiasiallisesti vaikuttaa yksilön hyvinvointiin ja elämään.

\section{Lähteet}

Avdagovska, M., Menon, D., \& Stafinski, T. (2020). Capturing the impact of patient portals based on the quadruple aim and benefits evaluation frameworks: Scoping review. Journal of medical Internet research, 22(12), e24568.

Charness, N., \& Boot, W. R. (2009). Aging and information technology use: Potential and barriers. Current Directions in Psychological Science, 18(5), 253-258. https://doi.org/10.1111/ j.1467-8721.2009.01647.x

Chesser, A., Burke, A., Reyes, J., \& Rohrberg, T. (2015). Navigating the digital divide: a systematic review of eHealth literacy in underserved populations in the United States. Informatics for Health \& Social Care, 1-19. https://doi.org/10.3109/17538157.2014.948171

Cotten, S. R., Anderson, W. A., \& McCullough, B. M. (2012). The impact of ICT use on loneliness and contact with others among older adults. Gerontechnology, 11(2), 161-165.

Coughlin, S. S., Stewart, J. L., Young, L., Heboyan, V., \& De Leo, G. (2018). Health literacy and patient web portals. International Journal of Medical Informatics, 113, 43-48. https://doi. org/10.1016/j.ijmedinf.2018.02.009

Crameri, K.-A., Maher, L., Van Dam, P., \& Prior, S. (2020). Personal electronic healthcare records: What influences consumers to engage with their clinical data online? A literature review. Health Information Management Journal. https://doi.org/10.1177/1833358319895369

Enwald, H. (2013). Tailoring Health Communication: The Perspective of Information Users' Health Information Behaviour in Relation to Their Physical Health Status. Doctoral dissertation. University of Oulu. http://urn.fi/urn:isbn: 9789526202792

Enwald, H. (2020). Combining personalization, tailoring, persuasive design and gamification - Where do we stand? Teoksessa Proceedings of the Eighth International Workshop on Behavior Change Support Systems. CEUR Workshop Proceedings, Vol. 2662. https://nbnresolving .org/urn:nbn:de:0074-2662-0 
Enwald, H., Hirvonen, N., Huotari, M.-L., Korpelainen, R., Pyky, R., Savolainen, M., . . Niemelä, R. (2016). Everyday health information literacy among young men compared with adults with high risk for metabolic syndrome - a cross-sectional population-based study. Journal of Information Science, 42(3), 344-355. https://doi.org/10.1177/0165551516628449

Enwald, H., Hirvonen, N., Kangas, M., Keränen, N., Jämsä, T., Huvila, I., \& Korpelainen, R. (2018). Relationship between everyday health information literacy and attitudes towards mobile technology among older people. Teoksessa Kurbanoğlu S., Boustany J., Špiranec S., Grassian E., Mizrachi D. and Roy L. (eds.), Information Literacy in the Workplace. ECIL 2017. Communications in Computer and Information Science, vol 810. Springer. https:// doi.org/10.1007/978-3-319-74334-9_47

Eriksson-Backa, K. (2010). Elderly people, health information, and libraries: a small-scale study on seniors in a language minority. Libri, 6o(2), 181-194. https://doi.org/10.1515/ libr. 2010.016

Eriksson-Backa, K. (2013). The role of online health information in the lives of Finns aged 65 to 79 years. International Journal of Networking and Virtual Organisations, 13(1), 5-23. https: // doi.org/10.1504/ijnvo.2013.058438

Eriksson-Backa, K., \& Ek, S. (2015). Health information literacy and communication in healthcare contexts: a study of older Finnish adults. Teoksessa Bath, P., Spring, H. and Sen, B. (eds.), Proceedings of the 17th International Symposium on Health Information Management Research (ISHIMR 2015), 24-26 June 2015 (pp. 77-91). York St. John University and University of Sheffield.

Eriksson-Backa, K., Enwald, H., Hirvonen, N., \& Huvila, I. (2018). Health information seeking, beliefs about abilities, and health behaviour among Finnish seniors. Journal of Librarianship and Information Science, 5O(3), 284-295. https://doi.org/10.1177/0961000618769971

Eriksson-Backa, K., Hirvonen, N., Enwald, H., \& Huvila, I. (2021). Enablers for and barriers to using My Kanta - A focus group study of older adults' perceptions of the National Electronic Health Record in Finland. Informatics for Health and Social Care. https://doi.org/10.1080 /17538157.2021.1902331

Eriksson-Backa, K., \& Nguyen, H. (2020). Health information-seeking styles and health information literacy in relation to anticipated health-promoting behaviour - results from an online diabetes risk test survey. International Journal of Telemedicine and Clinical Practices, 3(3), 192-208. http://dx.doi.org/10.1504/IJTMCP.2020.104893

Eysenbach, G. (2001). What is e-health? Journal of Medical Internet Research, 3(2), e20. https:// doi.org/10.2196/jmir.3.2.e20

Fischer, S. H., David, D., Crotty, B. H., Dierks, M., \& Safran, C. (2014). Acceptance and use of health information technology by community-dwelling elders. International Journal of Medical Informatics, 83(9), 624-635. https://doi.org/10.1016/j.ijmedinf.2014.06.005

Fletcher, J., \& Jensen, R. (2015). Overcoming barriers to mobile health technology use in the aging population. Online Journal of Nursing Informatics, 19(3). Noudettu osoitteesta http: //www . himss.org/ojni

Harst, L., Lantzsch, H., \& Scheibe, M. (2019). Theories predicting end-user acceptance of telemedicine use: Systematic review. Journal of Medical Internet Research, 21(5), e13117. https://doi.org/10.2196/13117 
Heart, T., \& Kalderon, E. (2013). Older adults: Are they ready to adopt health-related ICT? International Journal of Medical Informatics, 82(11), e209-e231. https://doi. org/10.1016/j.ijmedinf.2011.03.002

Hemsley, B., Rollo, M., Georgiou, A., Balandin, S., \& Hill, S. (2018). The health literacy demands of electronic personal health records (e-PHRs): An integrative review to inform future inclusive research. Patient Education and Counseling, 101(1), 2-15. https://doi.org/10.1016/j. pec.2017.07.010

Hirvonen, N., Enwald, H., Känsäkoski, H., Eriksson-Backa, K., Nguyen, H., Huhta, A.-M., \& Huvila, I. (2020). Older adults' views on eHealth services: a systematic review of scientific journal articles. International Journal of Medical Informatics, 135. https://doi. org/10.1016/j. ijmedinf. 2019.104031

Huvila, I. (2020). Aging, every-day information and technology use. Proceedings of the Annual Conference of CAIS / Actes Du Congrès Annuel de l'ACSI. CAIS/ACSI.

Huvila, I., Cajander, Å., Daniels, M., \& Åhlfeldt, R.-M. (2015). Patients' Perceptions of their Medical Records from Different Subject Positions. Journal of the Association for Information Science and Technology, 66(12), 2456-2470.

Huvila, I., Cajander, Å., Moll, J., Enwald, H., Eriksson-Backa, K., \& Rexhepi, H. (2021). Technological and informational frames: explaining age-related variation in the use of patient accessible electronic health records as technology and information. Information Technology \& People. https://doi.org/10.1108/ITP-08-2020-0566

Huvila, I., Ek, S., Enwald, H., Eriksson-Backa, K., Hirvonen, N. and Känsäkoski, H. (2016). Taking Health Information Behaviour into Account in the design of e-health services. Finnish Journal of eHealth and eWelfare, 8(4), 153-163. Noudettu osoitteesta https://journal.fi/ finjehew/article/view/60194

Huvila, I., Enwald, H., Eriksson-Backa, K., Hirvonen, N., Nguyen, H., \& Scandurra, I. (2018). Anticipating ageing: Older adults reading their medical records. Information Processing \& Management, 54(3), 394-407. https://doi.org/10.1016/j.ipm.2018.01.007

Huvila, I., Enwald, H., Eriksson-Backa, K., Liu, Y.-H., \& Hirvonen, N. (2019). Information behaviour and practises research informing technology and service design. Proceedings of the Association for Information Science and Technology, 56(1), 541-545. https://doi.org/10.1002/ pra2. 86

Huvila, I., Enwald, H., Hirvonen, N., \& Eriksson-Backa, K. (2019). The concept of usefulness in library and information science research. Information Research, 24(4), paper colis1907. Noudettu osoitteesta http://InformationR.net/ir/24-4/colis/colis1907.html

Huvila, I., Hirvonen, N., Enwald, H., \& Åhlfeldt, R.-M. (2019). Differences in health information literacy competencies among older adults, elderly and younger citizens. Teoksessa S. Kurbanoğlu, S. Špiranec, Y. Ünal, J. Boustany, M.L. Huotari, E. Grassian, D. Mizrachi et al. (eds.), Information Literacy in Everyday Life. ECIL 2018 (pp. 136-143). Communications in Computer and Information Science, vol 989. Springer. https://doi.org/10.1007/978-3-03013472-3_13 
Huvila, I., Moll, J., Enwald, H., Hirvonen, N., Åhlfeldt, R.-M., \& Cajander, Å. (2019). Age-related differences in seeking clarification to understand medical record information. Information Research, 24(1), paper isic1834. Noudettu osoitteesta http://InformationR.net/ir/24-1/ isic2018/isic1834.html

Hyppönen, H., Koch, S., Faxvaag, A., Gilstad, H., Nohr, C., Hardardottir, G. A., . . Vimarlund, V. (2017). Nordic eHealth Benchmarking: From Piloting towards Established Practice. Nordic Council of Ministers. https://doi.org/10.6027/TN2017-528

Hyppönen, H., Pentala-Nikulainen, O., \& Aalto, A.-M. (2018). Sosiaali- ja terveydenhuollon sähköinen asiointi 2017. Kansalaisten kokemukset ja tarpeet. Raportti 3/2018. Terveyden ja hyvinvoinnin laitos (THL). http: //urn.fi/URN: ISBN : 978-952-343-103-4

Jormanainen, V., Parhiala, K., Niemi, A., Erhola, M., Keskimäki, I., \& Kaila, M. (2019). Half of the Finnish population accessed their own data: comprehensive access to personal health information online is a corner-stone of digital revolution in Finnish health and social care. Finnish Journal of eHealth and eWelfare, 11(4), 298-310. https://doi.org/10.23996/fjhw.83323

Kauppinen, H., Ahonen, R., \& Timonen, J. (2017). The impact of electronic prescriptions on medication safety in Finnish community pharmacies: A survey of pharmacists. International Journal of Medical Informatics, 10O, 56-62. https://doi.org/10.1016/j.ijmedinf.2017.01.014

Kreps, G. L., \& Neuhauser, L. (2010). New directions in eHealth communication: Opportunities and challenges. Patient Education and Counseling, 78(3), 329-336. https://doi. org/10.1016/j.pec. 2010.01.013

Lee, B., Chen, Y., \& Hewitt, L. (2011). Age differences in constraints encountered by seniors in their use of computers and the internet. Computers in Human Behavior, 27(3), 1231-1237. https://doi.org/10.1016/j.chb.2011.01.003

Lämsä, E., Timonen, J., Mäntyselkä, P., \& Ahonen, R. (2017). Pharmacy customers' experiences with the national online service for viewing electronic prescriptions in Finland. International Journal of Medical Informatics, 97, 221-228. https://doi.org/10.1016/j. ijmedinf.2016.10.014

Mielonen, J., Saranto, K., Kuusisto, H., Kemppi, A., \& Kinnunen, U.-M. (2021). Ikääntyvien näkemyksiä sosiaali- ja terveydenhuollon sähköisistä palveluista. Gerontologia, 35(1), 3-12. https://doi.org/10.23989/gerontologia.89447

Morley, J. E. (2017). The new geriatric giants. Clinics in Geriatric Medicine, 33(3), xi-xii. https:// doi.org/10.1016/j.cger.2017.05.001

Muellmann, S., Forberger, S., Möllers, T., Bröring, E., Zeeb, H., \& Pischke, C. R. (2018). Effectiveness of eHealth interventions for the promotion of physical activity in older adults: A systematic review. Preventive Medicine, 108, 93-110. https://doi.org/10.1016/j.ypmed.2017.12.026

Nguyen, H., Eriksson-Backa, K., \& Enwald, H. (2018). Preliminary results of a survey on user opinions and experiences on an online diabetes risk test. PACIS 2018 Proceedings. 114. Noudettu osoitteesta https://aisel. aisnet.org/pacis2018/114/

Nikou, S. (2015). Mobile technology and forgotten consumers: the young-elderly. International Journal of Consumer Studies, 39(4), 294-304. https://doi.org/10.1111/ijcs.12187

Nissinen, S. P., Soini, S., Leino, T., Hakulinen, H., \& Saranto, K. (2018). Kanta-arkiston käyttökokemuksia työterveyshuollossa. Finnish Journal of eHealth and eWelfare, 10(1), 102-112. https://doi.org/10.23996/fjhw. 67815 
Nurgalieva, L., Cajander, Å., Moll, J., Åhlfeldt, R.-M., Huvila, I., \& Marchese, M. (2020). 'I do not share it with others. No, it's for me, it's my care': On sharing of patient accessible electronic health records. Health Informatics Journal, 26(4), 2554-2567. https://doi. org/10.1177/1460458220912559

Orlikowski, W. J., \& Gash, D. C. (1994). Technological frames: Making sense of information technology in organizations. ACM Transactions on Information Systems, 12(2), 174-207. https://doi.org/10.1145/196734.196745

Paige, S. R., Miller, M. D., Krieger, J. L., Stellefson, M., \& Cheong, J. (2018). Electronic health literacy across the lifespan: Measurement invariance study. Journal of Medical Internet Research, 20(7), e10434. https://doi.org/10.2196/10434

Palojoki, S., Pajunen, T., Saranto, K., \& Lehtonen, L. (2016). Electronic health record-related safety concerns: A cross-sectional survey of electronic health record users. JMIR Medical Informatics, 4(2), e13. https://doi.org/10.2196/medinform. 5238

Rexhepi, H., Moll, J., \& Huvila, I. (2020). Online electronic healthcare records: Comparing the views of cancer patients and others. Health Informatics Journal, 26(4), 2915-2929. https:// doi.org/10.1177/1460458220944727

Scharn, M., Sewdas, R., Boot, C. R. L., Huisman, M., Lindeboom, M., \& van der Beek, A. J. (2018). Domains and determinants of retirement timing: A systematic review of longitudinal studies. BMC Public Health, 18(1). https ://doi .org/10.1186/s12889-018-5983-7

Shaw, T., McGregor, D., Brunner, M., Keep, M., Janssen, A., \& Barnet, S. (2017). What is eHealth (6)? Development of a conceptual model for eHealth: Qualitative study with key informants. Journal of Medical Internet Research, 19(10), e324. https://doi.org/10.2196/jmir. 8106

Taipale, S., \& Hänninen, R. (2018). More years, more technologies: Aging in the digital era. Human Technology, 14(3), 258-263. https://doi.org/10.17011/ht/urn.201811224833

U.S. Department of Health and Human Services (2020). Topics and Objectives: Older Adults. Noudettu osoitteesta https://www. healthypeople.gov/2020/topics-objectives/topic/olderadults

Wandke, H., Sengpiel, M., \& Sönksen, M. (2012). Myths about older people's use of information and communication technology. Gerontology, 58(6), 564-570. https://doi. org/10.1159/000339104

Wildenbos, G. A., Horenberg, F., Jaspers, M., Peute, L., \& Sent, D. (2018). How do patients value and prioritize patient portal functionalities and usage factors? A conjoint analysis study with chronically ill patients. BMC Medical Informatics and Decision Making, 18(1), 108. https : // doi.org/10.1186/s12911-018-0708-5

Wilson, T. D. (2000). Human Information Behavior. Informing Science: The International Journal of an Emerging Transdiscipline, 3(2), 049-056. https://doi.org/10.28945/576

Wrzus, C., Hänel, M., Wagner, J., \& Neyer, F. J. (2013). Social network changes and life events across the life span: A meta-analysis. Psychological Bulletin, 139(1), 53-80. https://doi. org/10.1037/a0028601 